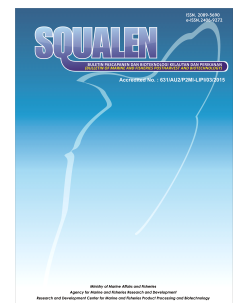

Squalen Bull. of Mar. \& Fish. Postharvest \& Biotech. 10 (3) 2015, 129-139

www.bbp4b.litbang.kkp.go.id/squalen-bulletin

Squalen Bulletin of Marine \& Fisheries Postharvest \& Biotechnology

ISSN: 2089-5690

e-ISSN: $2406-9272$

\title{
BIODIVERSITY OF CELLULOLYTIC BACTERIA ISOLATED FROM THE SOLID WASTES OF AGAR SEAWEED PROCESSING INDUSTRY
}

\author{
Ifah Munifah ${ }^{1,2}$, Titi Candra Sunarti ${ }^{2}$, Hari Eko Irianto ${ }^{3}$, and Anja Meryandini ${ }^{1}$ \\ ${ }^{1}$ Research and Development Center for Marine and Fisheries Product Processing and Biotechnology, \\ Jalan KS. Tubun Petamburan VI, Slipi, Central Jakarta 10260, Indonesia; \\ ${ }^{2}$ Department of Biology, Faculty of Mathematics and Natural Sciences, Bogor Agricultural University, \\ Jalan Raya Dramaga Kampus IPB, Bogor, Indonesia 16680; \\ ${ }^{3}$ Research Center for Fisheries Management and Conservation Ministry of Marine Affairs and Fisheries, \\ JI. Pasir Putih II, Ancol Timur, Jakarta 14430, Indonesia. \\ Article history: \\ Received: 15 September 2015; Revised: 10 November 2015; Accepted: 23 November 2015
}

\begin{abstract}
Agar is polysaccharide extracted from the seaweed Gracilaria sp. It is commonly used for food, medical, pharmaceutical and biotechnology industries. The red seaweed Gracilaria verrucosa is the most common material used for the extraction of agar, processed into sheet and powder. A total of 7169 tons solid waste is produced from the agar industry in Indonesia which can further result in 4301.4 tons per year of cellulose. However, solid wastes from agar seaweed processing industry have not been managed and used optimally, and therefore seaweed solid wastes can be used as one of alternative source of cellulose and cellulolytic bacteria. In this research, we reported the isolation of cellulose-producing bacteria from seaweed processing industry wastes using specific media $1 \%$ LIA (Limbah Industri Agar, waste of seaweed processing industry). Sequencing and subsequent phylogenetic analysis of the 16S rRNA genes amplified from the obtained 7 isolates identified them as Serratia marcescens, Chryseobacterium indovlogenes, Bacillus pumilus, Bacillus cereus, Strenatrophomonas maltophila, and Pseudomonas aeruginosa.
\end{abstract}

Keywords: solid waste, seaweed processing, cellulolytic bacteria

\section{Introduction}

Ministry of Marine Affairs and Fisheries of Indonesia (KKP) estimates that 15 percent of Indonesian seaweed will dominate the world market of seaweed (P2HP, 2012). The increasing utilization of agar polysaccharides has caused the increased demand of raw material in agar industry, producing wastes that become potential problems for environment. However, management of solid wastes released by the seaweed processing industry itself has not become the focus of attention. Most wastes produced from seaweed processing only end up as organic wastes which have not been used optimally. The principle of "Zero Waste Industry" needs to be applied by converting agar seaweed wastes into "a value-added product" that has much higher value compared with the initial value of the product (waste).
Seaweed has significant differences compared to terrestrial plants, in term of chemical composition, physiology, and morphology. Carbohydrate content and composition of macroalgae are abundant and vary among different species. The percentage of carbohydrates in green, red, and brown seaweeds is $25-50 \%, 30-60 \%$, and $30-50 \%$, respectively (Jung et al., 2013).

Meanwhile, solid waste of seaweed processing industry (agar) contains agar, mineral celite, and also holocellulose. The dry waste is physically very hard because the presence of mineral celite in it. Celite $\left(\mathrm{SiO}_{2}\right)$ is an inert mineral used as important filter and carrier agent, and therefore is widely used as filtering agent in the seaweed processing industry. In Indonesia, solid waste from seaweed processing is still one of the environmental problems that needs special handling, because its amount reaches 1 ton

${ }^{*}$ Corresponding author.

E-mail: ifah_munifah@yahoo.com.au 
million in one day. This is exemplified by the solid wastes released by the seaweed processing industry, CV. Agar Sari Jaya Karanglo, Malang, East Java, Indonesia. The wastes produced by the industry contain mineral celite, and therefore, it needs a large place for storage, because the odors can penetrate into the surrounding environment. Utilization of industrial agar waste to produce an economically valuable product is a solution due to the high content of polysaccharides. So far, there are still no study about utilization of waste containing celite, and therefore we intended to determine whether the existence of celite in solid waste affect the hydrolysis process of solid waste.

Approximately $65-75 \%$ of solid waste can be yielded from production process of agar. Solid waste from agar seaweed processing still contains cellulose in the range of $15-25 \%$ (Kim et al., 2007). The cell walls of seaweed is more complex and more vary than terrestrial plants, which is generally composed of a mixture of sulfuric and branched polysaccharides associated with proteins and binding of various kinds of ions such as calcium and potassium. Red seaweed has a cell wall composed of cellulose, xylan, and carrageenan (Wijengsihe \& Jeon, 2012), making it as a potential source of cellulose. In this paper we used solid waste as a source of cellulose in order to make specific media for isolating cellulolytic bacteria. Cellulolytic enzymes are generally produced naturally by a wide range of microbial communities, including bacterial and fungal species. Some of microbial members are able to biosynthesize different types of cellulolytic enzymes and convert a cellulose plant into simple reducing sugars (Lynd et al., 2002; Hasunuma et al., 2013). Our present study was aimed to isolate and identify cellulolytic bacteria in solid wastes of agar seaweed processing industry. It is expected that the result of this study can give an information regarding the potential bacteria for biodegradation and biotechnological applications.

\section{Material and Methods}

\subsection{Sources of Strain}

Bacterial strain used in our present study was isolated from decayed solid waste of seaweed processing industry (agar) in Malang, East Java. Tenfold serial dilution of the samples was used for isolating cellulolytic bacteria. One gram sample of the decayed seaweed solid waste was diluted aseptically on to $9 \mathrm{ml}$ of $0.85 \% \mathrm{NaCl}$ physiological solution and homogenized in room temperature. A total of $0.1 \mathrm{ml}$ sample was spreaded on to the surfaces of plates containing $1 \%$ of LIA agar, $\mathrm{pH}$ 7.0. LIA agar medium was prepared in medium containing $1.0 \mathrm{~g} / \mathrm{L}$ of
$\mathrm{KH}_{2} \mathrm{PO}_{4} ; 2 \mathrm{~g} / \mathrm{L}$ of $\mathrm{K}_{2} \mathrm{HPO}_{4} ; 0.5 \mathrm{~g} / \mathrm{L}$ of $\mathrm{MgSO}_{4} \cdot 7 \mathrm{H}_{2} \mathrm{O}$; $0.5 \mathrm{~g} / \mathrm{L}$ of $\mathrm{NaCl} ; 0.01 \mathrm{~g} / \mathrm{L}$ of $\mathrm{FeSO}_{4} .7 \mathrm{H}_{2} \mathrm{O} ; 2 \mathrm{~g} / \mathrm{L}$ of yeast extract; $0.01 \mathrm{~g} / \mathrm{L}$ of $\mathrm{MnSO}_{4} \cdot \mathrm{H}_{2} \mathrm{O} ; 0.3 \mathrm{~g} / \mathrm{L}$ of $\mathrm{NH}_{4} \mathrm{NO}_{3} ; 10.0 \mathrm{~g} / \mathrm{L}$ of LIA; $12.0 \mathrm{~g} / \mathrm{L}$ of agar. Plates were incubated at $37^{\circ} \mathrm{C}$ for 5 days to allow cellulase secretion. After certain time of incubation, the plates were stained by congo red to check the cellulolytic activity of isolated strains. The cellulase activity of each culture was determined by measuring the clearance zone on agar plate. Total of 53 isolates were obtained by the primary screening from which 7 isolates were showing potential activity. These seven isolates were selected and determined cellulolytic enzymes production in the presence of CMC.

\subsection{Source of LIA (Limbah Industri Agar) Substrat}

Industrial solid seaweed processing wastes (agar) was collected from CV. Agar Sari Malang. Solid seaweed wastes were grinded, sieved, and stored at $2{ }^{\circ} \mathrm{C}$ for further use. The size of the samples was selected at 200 mesh $(75 \mu \mathrm{m})$ to make sure that the enzyme and fibers have optimum contact during the hydrolytic reaction.

\subsection{Preparation of Media}

Liquid used for medium dilution was $0.85 \%$ of $\mathrm{NaCl}$ physiological solution. Specific medium was prepared as described by Huang et al. (2012) and Johnsen \& Krause (2014) with some modifications, as follows : $1.0 \mathrm{~g} / \mathrm{L}$ of $\mathrm{KH}_{2} \mathrm{PO}_{4} ; 2 \mathrm{~g} / \mathrm{L}$ of $\mathrm{K} 2 \mathrm{HPO} 4 ; 0.5 \mathrm{~g} / \mathrm{L}$ of $\mathrm{MgSO}_{4} .7 \mathrm{H}_{2} \mathrm{O} ; 0.5 \mathrm{~g} / \mathrm{L}$ of $\mathrm{NaCl} ; 0.01 \mathrm{~g} / \mathrm{L}$ of $\mathrm{FeSO}_{4} .7 \mathrm{H}_{2} \mathrm{O}$; $2 \mathrm{~g} / \mathrm{L}$ of yeast extract; $0.01 \mathrm{~g} / \mathrm{L}$ of $\mathrm{MnSO}_{4} \cdot \mathrm{H}_{2} \mathrm{O} ; 0.3 \mathrm{~g} /$ $\mathrm{L}$ of $\mathrm{NH}_{4} \mathrm{NO}_{3} ; 10.0 \mathrm{~g} / \mathrm{L}$ of LIA. $\mathrm{pH}$ medium was adjusted to 7.0 with $1 \mathrm{M} \mathrm{NaOH}$. The media were sterilized at $121^{\circ} \mathrm{C}$, for $20 \mathrm{~min}$.

\subsection{Cellulolytic Enzyme Assays on CMC as Major Carbon Source}

To study the potential cellulolytic activity of selected seven isolates, their enzyme activites on carboxy methyl cellulose (CMC) substrates were studied. Starter cultures of selected isolates were prepared by transferring cellulolytic cells with an inoculation loop from the CMC agar plates onto 100 $\mathrm{ml}$ of liquid medium at $1 \% \mathrm{CMC}$ as major carbon source. The initial pH was adjusted to 7.0. The cultures further incubated on a shaker at $150 \mathrm{rpm}$ for $120 \mathrm{~h}$ at $37^{\circ} \mathrm{C}$. Culture samples were taken every $12 \mathrm{~h}$ during incubation. The cell free supernatants were obtained by centrifugation $(10,000 \times \mathrm{g}, 10 \mathrm{~min})$ and then analyzed for cellulolytic activities.

In order to determine cellulolytic activity of culture, the standard assay was performed using supernatant. Assay of cellulolytic enzyme activities was based on 
the determination of the amount of reducing sugars liberated from carboxy methyl cellulose (CMC) (Romano et al., 2013). Endoglucanase (CMCase) activity was determined by incubating $0.5 \mathrm{ml}$ of enzyme solution with $0.5 \mathrm{ml}$ of $1 \% \mathrm{CMC}$ in citrate buffer ( $\mathrm{pH}$ 4.5.0) and incubated at $37^{\circ} \mathrm{C}$ for $30 \mathrm{~min}$. The reaction was terminated by adding $3 \mathrm{ml}$ DNS (dinitrosalicylic acid) reagent and heating in boiling water bath for $10 \mathrm{~min}$. One unit of enzyme CMCase activity in each case was defined by the amount of enzyme that produces $1 \mu \mathrm{mol}$ of reducing sugar from the substrate per minute.

\subsection{DNA Extraction and PCR Amplification of 16S rRNA Bacteria}

Identification of selected isolate was done using 16S rRNA gene sequence analysis. For this purpose, DNA extraction from the strain was done using Genomic DNA Purification Kit (Fermentas) according to the manufacturer's recommendations. PCR analysis was done using general primer and software PCR Taq Ready To Go PCR beads (GE Healthcare), then the result was sequenced and analyzed through BLAST (Basic Local Alignment Sequensing Tools) (Pozo et al., 2012). Seven selected isolates as LA3, LA4 K, LA4 P, L45C, LB3, L271, and L24 were performed with the sequencing process services company sequencing (Macrogen Inc., South Korea). Sequenced data were then processed further using Bioedit software. Further alignment was done with the database on www.ncbi.nlm.nih.gov/ and manufacture of phylogeny tree using http://www.phylogeny.fr/.

\section{Results and Discussion}

One of carbohydrate's component in solid waste produced by agar seaweed processing industry is cellulose. Cellulose is a structural framework of all plants. Cellulose is the main part of plant cell walls which are composed of 10,000 units of glucose in the form of units hydroglucopyranose formula $\left[\mathrm{C}_{6} \mathrm{H}_{10} \mathrm{O}_{5}\right] \mathrm{n}$ (Siddhanta et al., 2009).

Through secretion of cellulases as single enzymes, as single polypeptides with multiple cellulosic domains or as extracellular multienzyme complexes, microorganisms have developed several strategies to digest cellulose. The degradation of cellulose is accomplished through the action of enzymes that include endo-1,4- $\beta$-glucanases and exo$1,4-\beta$-glucanases (cellobiohydrolases) (Lynd et al., 2002). Endoglucanases are able to hydrolyze amorphous cellulose, carboxymethylcellulose, and phosphoric acid-swollen cellulose, producing soluble oligosaccharides that are subsequently degraded into cellobiose and glucose through the action of $\beta$ glucosidase. Cellobiohydrolases degrade cellulose by cleaving cellobiose units from the non-reducing end of a cellulose fibre (Lynd et al., 2002).

Isolates with great value and clear IS are considered to have high activities. Based on this qualitative test results, we obtained isolates that have cellulolytic activity. Cellulolytic index is the ratio between the clear zone to colony diameter. To measure the cellulolytic activity, quantitative assay using the DNS method was subsequently pursued (Ariffin et al., 2008; Del Pozo et al., 2012). There were 53 from the total of 121 isolates exhibiting the ability to produce cellulase enzymes indicated with a clear zone around the colonies after growth in media containing $1 \%$ LIA and flooded by Congo red. Furthermore, total 7 out of 53 isolates exhibited bigger cellulolytic activities than that of other isolates.

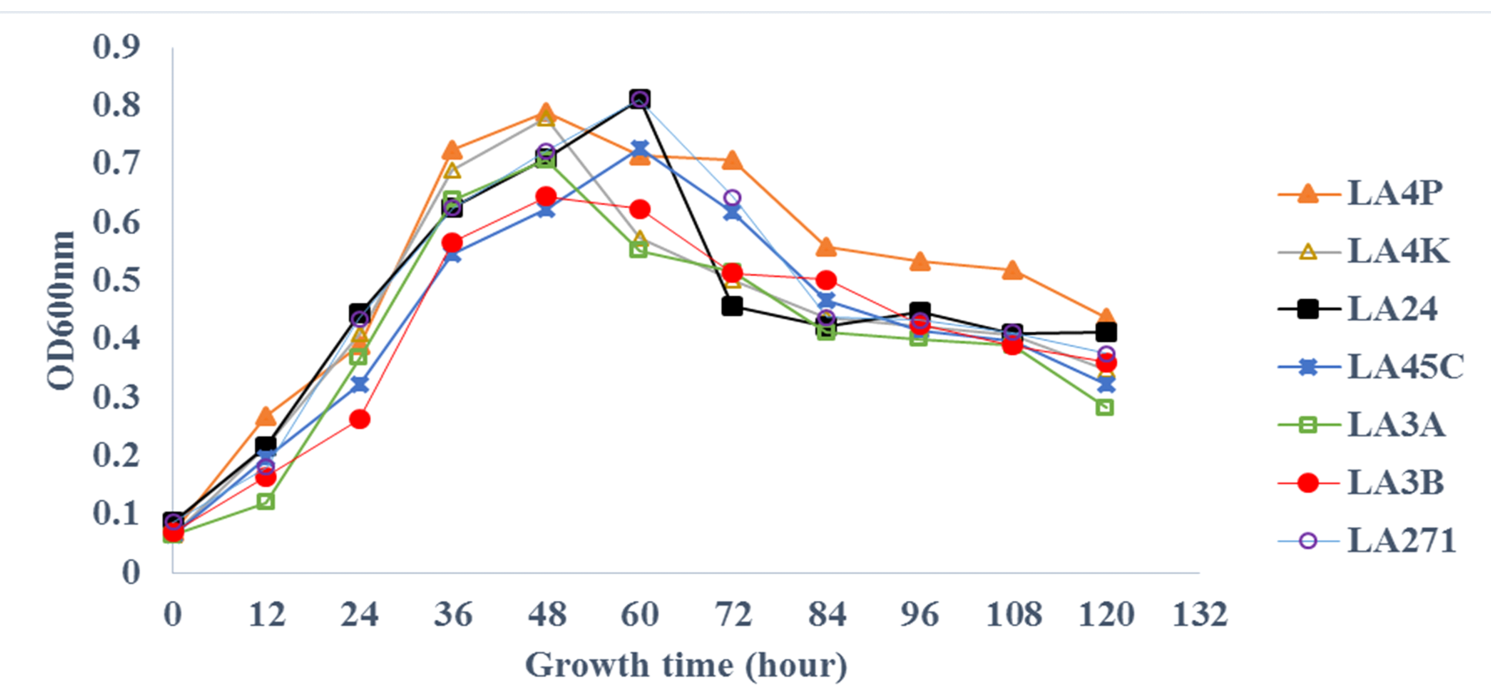

Figure 1. Growth curve of seven selected cellulolytic isolate in CMC culture broth. 


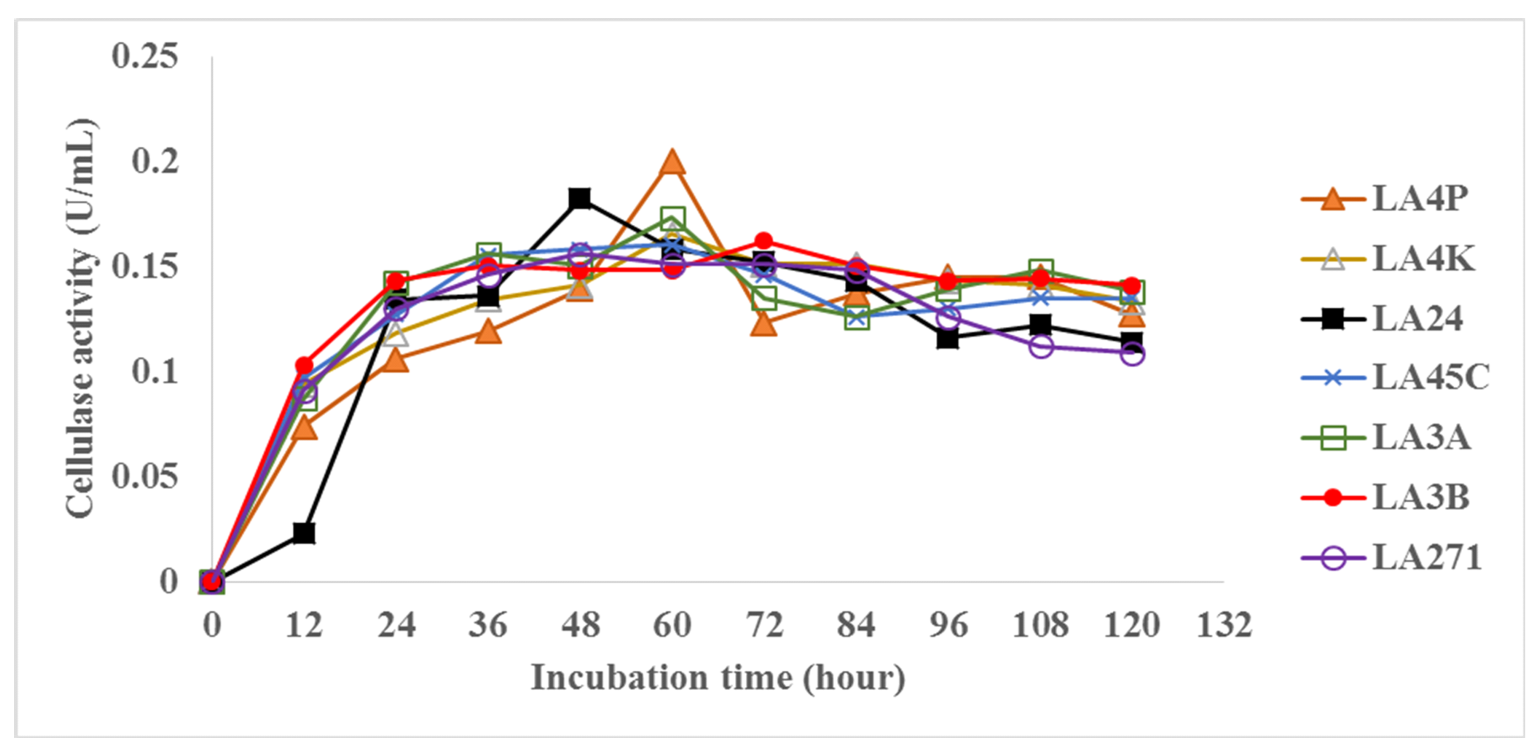

Figure 2. Activity of enzyme hydrolyzing CMC of seven isolates tested.

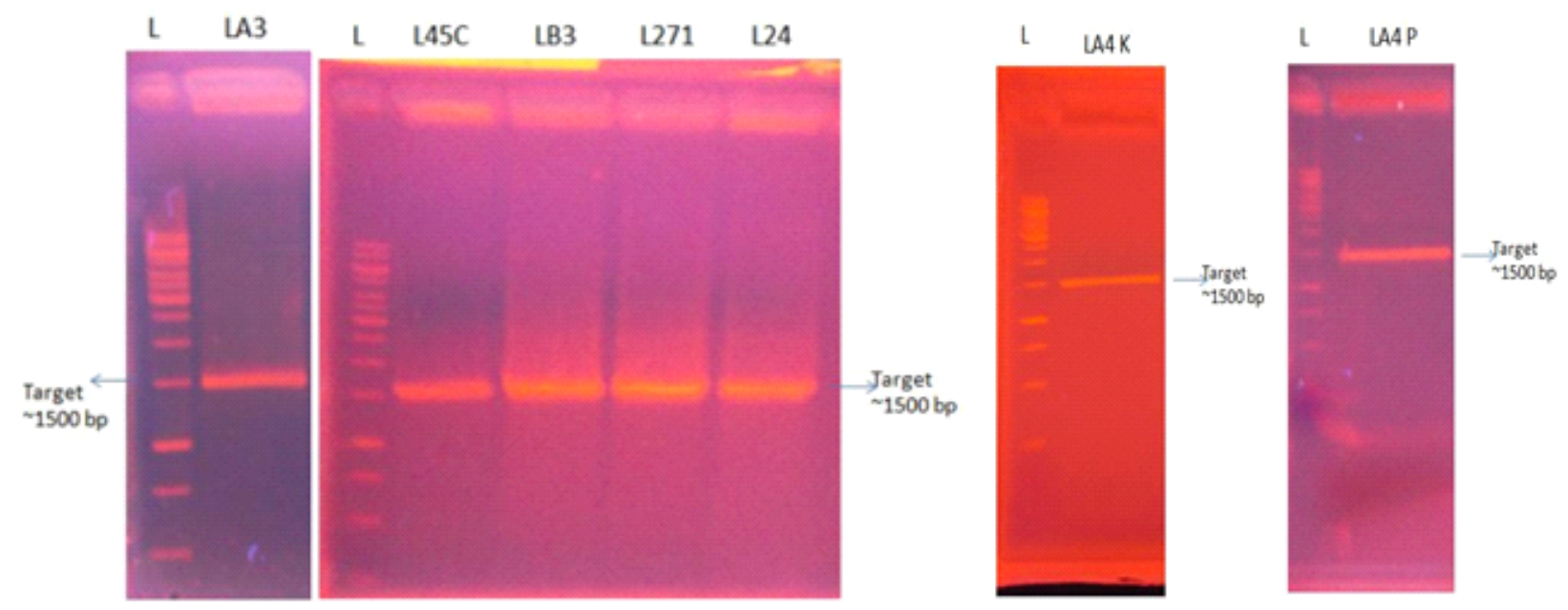

Figure 3. Gel electrophoresis of $16 \mathrm{~S}$ rDNA fragment of seven selected isolate.

Based on the curve at the Figure 1, almost all seven selected isolates showed high biomass at the exponential/logarithmic growth phase at the incubation time of $36 \mathrm{~h}$, and therefore it was considered as the appropriate time to transfer the starter culture into production medium. At the logarithmic phase, bacterial cultures multiply quickly at the significant cell mass so that the bacteria in good condition to be used as the inoculum. This is an appropriate phase to pour the starter into production medium, because it didn't take long time for bacteria in adaptation phase at media production, so that production of cellulase enzymes can be expected more quickly.

Using CMC as substrate, Figure 2 shows that all tested isolates showed an increased endoglucanase activity over the period of 60-72 h. Among the isolates tested, LA4P isolates were estimated to have the maximum activity of $0.2 \mathrm{U} / \mathrm{ml}$ at $60 \mathrm{~h}$ after incubation.

Seven selected cellulolytic bacterial isolates were LA3, LA4K, L45C, LA4P, LA3B, LA271, and LA24. Bacterial isolates were grown in nutrient broth medium at $37^{\circ} \mathrm{C}$ for $24 \mathrm{~h}$ and centrifuged at $10,000 \times g$ for 10 min to remove the supernatant.

Fragments of 16 s rRNA gene from the seven isolates were amplified by PCR. The amplification products (around $1500 \mathrm{bp}$ ) shown in Figure 3 were individually sequenced.

Based on the results of alignment with the database, the sample LA3 has similarities to Serratia marcescens with the identity value of $99 \%$ (Table 2 ). Phylogenetic tree of the LA3 isolate was 
Table 1. CMCase activities of seven selected isolates from solid waste of seaweed processing industry

\begin{tabular}{lcc}
\hline Isolates & Activity $(\mathbf{U} / \mathbf{m l})$ & Period of incubation (hours) \\
\hline LA3B & 0.162237 & 72 \\
LA24 & 0.182279 & 48 \\
LA271 & 0.156225 & 48 \\
LA45C & 0.160233 & 60 \\
LA4K & 0.165244 & 60 \\
LA4P & 0.200317 & 60 \\
LA3A & 0.173260 & 60 \\
\hline
\end{tabular}

reconsctructed using reference sequence to Serratia genus reference with the identity at least $90 \%$ (Figure 4).

Seven selected cellulolytic isolates were combined in a single phylogenetic tree to determine the relationship among other isolates (Figure 5). Clade I contained of LA3, it can be seen that LA3; isolates has closed relations with Serratia marcescens with similiarity value of $99 \%$. This clade contained LA271 and LA3A which all had identity 93 and $99 \%$ as Pseudomonas aeruginosa and Serratia marcescens (Table 2). Based on the alignment results with the data base, LA271 isolates has similarity with bacteria from the group Pseudomonas aeruginosa with identity value of $93 \%$. Furthermore, phylogenetic tree reconstruction was performed using sequence references from the genus Pseudomonas to minimal identity value at least $90 \%$. Outgroup bacteria used for phylogenetic tree reconstruction was Shewanella morhuae.

Based on the calculation results from phylogram, it can be seen that LA271 isolates have close relations with Pseudomonas aeruginosa with similarity value of $91.6 \%$. Pseudomonas spp. is a nonpathogenic soil bacterium, that produces greenish fluorescent pigment. The role of Pseudomonas spp. bacteria in the biodegradation plant growth promoting activities, and detoxification of the toxicants is well documented (Wasi et al., 2013; Souza et al., 2014; Paraneeiswaran et al., 2014; Islam et al., 2014). Various Pseudomonas spp. strains have been reported to have potential biosurfactant activity and detoxification certain organic and inorganic water pollutants (Souza et al., 2014). A promising bioremediation approach was developed to remove [Co(III)-EDTA] complex that is generated during the waste management process by a halophilic solar-salt-pan isolate Pseudomonas aeruginosa SPB-1 (Paraneeiswaran et al., 2014). Sharma et al. (2014) stated that Pseudomonas spp. has ability as bioremediant of crude oil in contaminated soil. It concluded that it was an effective process to clean petroleum contaminant from the environment. Islam et al. (2014) concluded that P.aeruginosa is an ideal candidate for bioremediation and wheat growth promotion against $\mathrm{Zn}$-induced oxidative stress by improving the availability of necessary nutrient,eliciting antioxidant defense system as well as lowering the Zn metal uptake. Zinc resistant isolates Pseudomonas aeruginosa showed multiple plant growth promoting activities, when this bacterium was inoculated under Zn stress, it significantly increased root and shoot length as well as the total dry weight of plants (Islam et al., 2014).

The second clade contained LA3B and LA24 which all had 97 and $92 \%$ of identity to Strenatrophomonas maltophila. Based on the alignment results with the database, LA3B isolates have similarity with bacteria from the group Stenotrophomonas maltophila with $97 \%$ identity value. Furthermore, phylogenetic tree reconstruction was performed using sequence references from the genus Bacillus with minimal identity value of least $90 \%$. Outgroup bacteria used for phylogenetic tree reconstruction was Xylella fastidiosa.

Based on the alignment results with the database, LA24 isolates had similarity to bacteria from the group Stenothrophomonas maltophila with $90 \%$ identity value. Furthermore, phylogenetic tree reconstruction was performed using sequence references from the genus Stenotrophomonas with minimal identity value at least $90 \%$. Outgroup bacteria used for phylogenetic tree reconstruction was Shewanella morhuae.

Based on the calculation results from phylogram, it can be seen that LA3B and LA271 isolates had the same result as Stenotrophomonas maltophila, but with quite different similarity value. LA3B and LA24 isolates have close relations with Stenotrophomonas maltophila with similarity value of $96.7 \%$ and $92.4 \%$. 


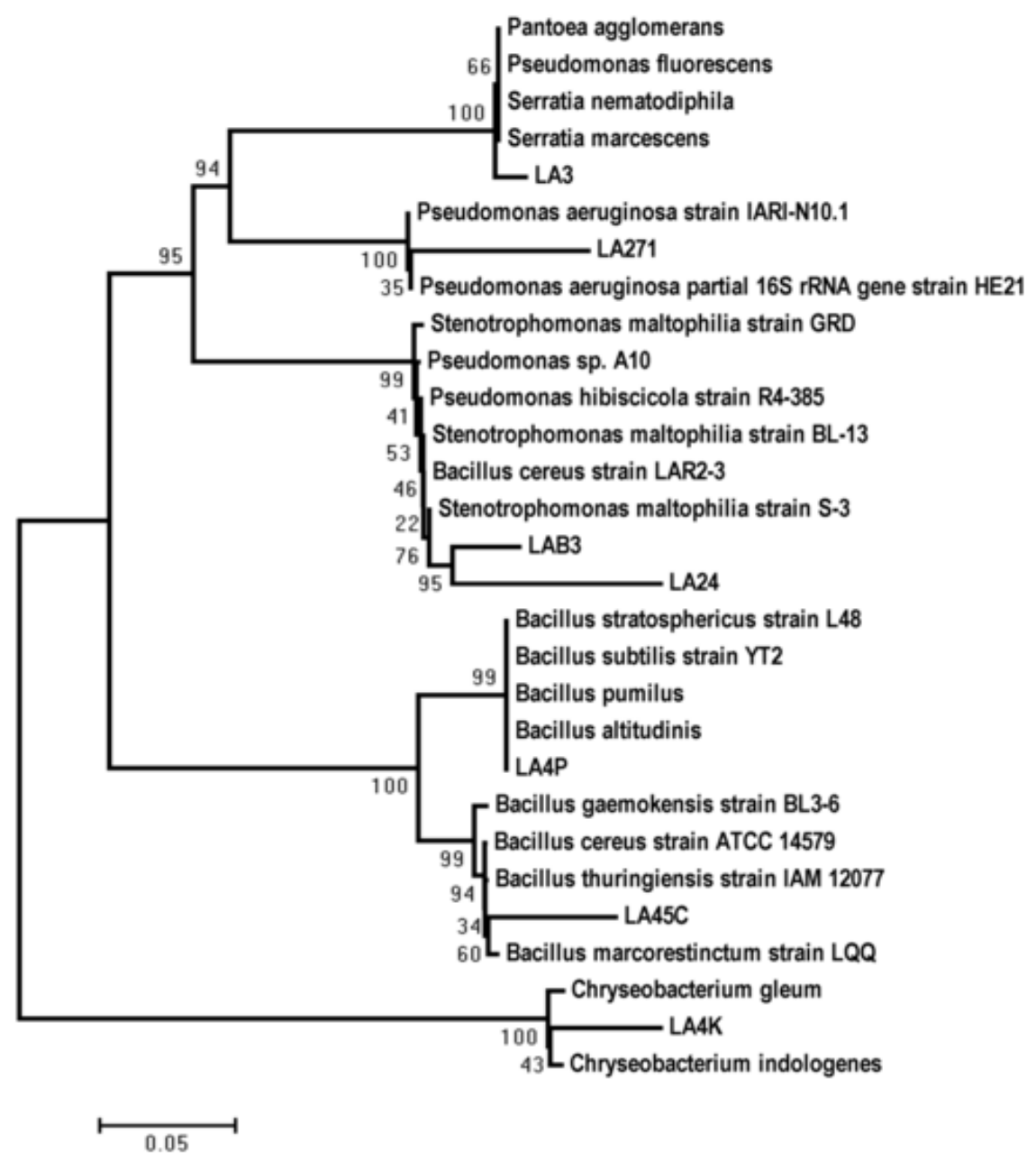

Figure 4. Phylogenetic relationship based on 16s rRNA sequences of seven selected isolates from agar seaweed waste. The tree was constructed using sequences of comparable region of the 16S rRNA gene sequences available in public databases.Neighbour-joining analysis using 100 bootstrap replicates was used to infer tree topology. The scale bar shows the number of nucleotide substitutions per site of $5 \%$. Evolutionary distances between sequences estimated by computing the proportion of nucleotide differences between each pair of sequences using the program MEGA5.

Tabel 2. Result analysis of sequencing selected isolate from solid waste of seaweed processing industry.

\begin{tabular}{|c|c|c|c|}
\hline & \multirow{2}{*}{$\begin{array}{l}\text { Code of isolates: } \\
\text { Taxon assignment }\end{array}$} & \multicolumn{2}{|c|}{ Sequensing 16 s rRNA result analysis } \\
\hline & & $\%$ similiarity & Cellulolytic index \\
\hline LA3A & : Serratia marcescens & 99 & 2.75 \\
\hline LA4K & : Chryseobacterium indologenes & 96 & 2.57 \\
\hline LA4P & : Bacillus pumilus & 93 & 7 \\
\hline LA45C & Bacillus cereus & 96.1 & 0.4 \\
\hline LA3B & Strenatrophomonas maltophila & 97 & 3 \\
\hline LA271 & : Pseudomonas aeruginosa & 93 & 4 \\
\hline LA24 & Strenatrophomonas maltophila & 92 & 11.0 \\
\hline
\end{tabular}


Stenotrophomonas maltophilia is an aerobic, nonfermentative, gram negative bacterium. It is an uncommon bacterium and can cause human infection which is difficult to treat. Some studies have reported that Stenotrophomonas maltophila is a significant nosocomial pathogen, responsible for an increasing number of infections, particulary in immunocompromised patients (Garazi et al., 2012).

Some literature also mentions that Stenotrophomonas maltophila was applied in bioremediation processes to reduce the concentration and the toxicity of various pollutants, including petroleum products (Gargouri et al., 2011; Hassanshahian et al., 2013; Patel et al., 2013; Salek et al., 2013; Gao et al., 2014; Sarma et al., 2014).

Gargouri et al. (2011) revealed that the application of an aerobic Stenotrophomonas maltophilia CSTR (continuously stirred tank bioreactor) for the treatment of hydrocarbon-contaminated wastewater is an effective bioremediation technology. Hassanshahian et al. (2013) in his paper conclude that Stenotrophomonas maltophilia has ability to degrade hexadecane more diversity and ability to biodegrade waste water petroleum reservoirs in Iran. Patel et al., (2013) studied that Strenotrophomonas malthophilia bacteria in a phenanthrene-degrading bacterial consortium (ASP) degraded phenanthrene in the presence of other pollutants, revealing that it efficiently utilized phenanthrene in the presence of a mixture of pollutants. Salek et al. (2013) reported that Stenotrophomonas maltophilia bacteria can use different substances for their growth including both diesel oil and polyglucosides.

Biosorption and biodegradation of triphenyltin by Stenotrophomonas maltophilia and their influence on cellular metabolism was studied by Gao et al. (2014). The results verified that Stenotrophomonas maltophilia can effectively adsorb and degrade triphenyltin. Triphenyltin (TPT) was initially adsorbed by the cell surface of Stenotrophomonas maltophilia and was subsequently trans-ported and degraded intracellularly by diphenyltin and monophenyltin production.

The next clade were LA4P and LA45C which all had 93 and $96.1 \%$ identity as Bacillus pumilus and Bacillus cereus (Figure 4). Based on the alignment results with the database, LA4P isolates has similarity with bacteria from the group Bacillus pumilus with $99 \%$ identity value. Furthermore, phylogenetic tree reconstruction was performed using sequence references from the genus Bacillus with minimal identity value of at least $90 \%$. Based on the calculation results from phylogram (Figure 4), it can be seen that LA4P isolates have close relations with Bacillus pumilus with similarity value of $98.9 \%$. LA4P isolates is a spore forming bacteria that is rod shape, gram positive, and aerobic. Bacillus species constitute a diverse group of bacteria widely distributed in soil and aquatic environment. Bacillus pumilus who resides in soils and colonize in root plants has several bioactivities. Previous researcher reported the use of Bacillus pumilus in various industry as biocatalyst (Akbulut et al., 2013; Kuppers et al., 2014), biofuel (Edembe et al., 2012; Suraniti et al., 2013) and bioremedian (Watharkar et al., 2013).

The study by Watharkar et al. (2013) revealed the beneficial phytoremediation potential of Bacillus pumillus to degrade and decolorize the dye Navy Blue $\mathrm{RX}$ in to noteworthy level, released less toxic metabolites dye. Edembe et al. (2012) and Suraniti et al. (2013) studied the catalytic performance of bilirubin oxidase (BOD) from Bacillus pumilus and it showed high thermostability. The reported thermostable BOD was a promising alternative to the currently used BOD in biofuel cells and may open new perspectives for their use of biofuel cells in various bioelectronics applications. Luz et al. (2010) and Ahmad et al. (2012) had reported that Bacillus pumilus has great potential for remediating soil contaminated with organic compounds such as pesticides residues in crop plants and enhancing plant growth in mine tailings.

Based on the calculation results from phylogram, it can be seen that $L A 45 C$ isolates have close relations with Bacillus cereus with similarity value of $96.1 \%$. The role of Bacillus cereus as bioremidiant agent had been reported by previous researcher (Gargouri et al., 2011; Sarma et al., 2014; Ghorbel-Bellaj et al., 2012; Huang et al., 2012; Sriram et al., 2015; Kadam et al., 2012; Tripathi et al., 2014). Bioremediation processes, which take advantage of microbial degradation of organic compounds, can be defined as the use of microorganisms (especially bacteria) to detoxify and to remove pollutants from environment either from soils, waters and sediments (Gargouri et al., 2011).

Gargouri et al. (2011) used Bacillus cereus to treat hydrocarbon-rich industrial wastewaters using a continuously stirred tank bioreactor. The treatment provided satisfactory results and presented a feasible technology for the treatment of hydrocarbon-rich industrial wastewaters from petrochemical industries and petroleum refineries. Similar work was also done by Sarma et al. (2014), who reported that crude oil contaminated with soil is a good habitat for potentialhydrocarbon degrader bacteria such as Bacillus cereus.

Cellulolytic bacteria species generally are found within the phyla of Thermotogae, Proteobacteria, Actinobacteria, Spirochaetes, Firmicutes, 
Fibrobacteres and Bacteroids. Of these, approximately more than $80 \%$ of the isolated cellulolytic bacteria are found within phyla Firmicutes and Actinobacteria (Bergquist et al.,1999). Organisms that are capable of degrading the natural polymer and utilizing it as a source of carbon are ecologically very important. Cellulose is generally completely degraded into $\mathrm{H}_{2} \mathrm{O}$ and $\mathrm{CO}_{2}$ in aerobic systems while in anaerobic systems $\mathrm{CH}_{4}$ and $\mathrm{H}_{2}$ are also produced. Although, most cellulose is degraded by microbe in aerobic environments, 5 to $10 \%$ is degraded under anaerobic conditions by a range of physiologically diverse bacteria (Lynd et al., 2002). Among these cellulolytic bacteria class Clostridia have been well studied and characterized. These bacteria are ubiquitous found in anaerobic soil environments, forming endospores and digesting cellulose via an exocellular enzymatic complex called a cellulosome as well as, converting cellulose into several different metabolites (Lynd et al., 2002).

Araujo et al. (2010) and Chan et al. (2013) revealed the ability of Serratia marcescens as biodegradation agent. Serratia marcescens UCP/WFCC 1549 produced biosurfactant using waste as alternative substrate which allows a reduction of fermentation and costs of the process (Chan et al., 2013).

A suitable strain for bioremediation of soils contaminated with OPPs identified as Serratia marcescens has ability of diazinon-degrading to remove organophosphorus pesticides (OPPs) as chlorpyrifos (CP), fenitrothion (FT), and parathion (PT) in sandy, sandy loam and silty soils (Cycon et al., 2013). Araujo et al. (2010) also has studied that Serratia marcescens presents in effluents from the process of iron ore flotation as the microorganisms responsible for fatty amine degradation.

The last clade was LA4K isolates. It has similiarity with bacteria from the group Chryseobacterium indologenes with $96 \%$ identity value. Furthermore, phylogenetic tree reconstruction was performed using sequence references from the genus Chryseobacterium with minimal identity value at least $90 \%$. Outgroup bacteria used for phylogenetic tree reconstruction was Leeuwenhoekiella marinoflava. Based on the calculation results from the phylogram (figure 4), it can be seen that LA4K isolates have close relations with Chryseobacterium indologenes with similarity value of $94.8 \%$. LA4K isolates is a nonmotile, gram negative bacillus, catalase and oxidase positive, indole positive, non-fermentative, and yellow pigmented bacteria. The 16S rRNA gene sequence analysis of strain LA4K indicated that Chryseobacterium indologenes is the closest related species with a pair wise sequence similarity of $94.8 \%$.
Some literature stated that member Chryseobacterium were found in rhizosphere (Cho et al., 2010), water (Kumar et al., 2011), soil, fish (Zamora et al., 2012; Boran et al., 2013), mid gut of insect (Kampfer et al., 2010), clinical samples (Buresova et al., 2009; Calderon et al., 2011; Chang et al., 2014).

Previous studied revealed that Chryseobacterium indologenes is keratinase producer (Wang et al., 2008), important bacterial group associated with plants in rhizosphere soil (Venil et al., 2014; Anderson \& Habiger, 2012), and exhibits plant growth promoting activities (Montero-Calasanz et al., 2013).

Seven selected isolate were growing well in solid waste of agar seaweed processing industry. Although it still contained mineral celite, they have potential activity to degrade in solid waste of agar seaweed processing industry. Several studies suggest that celite can be used as biocompatible solid supports for immobilizing enzymes. Mc Minn et al. (2012) using celite for recovery of enteric adenoviruses 40 and 41 ; Sharma et al. (2014) using celite at the proses to synthesis of alkyl coumarate esters by celite-bound lipase of Bacillus licheniformis SCD11501. Ansari and Husein (2012) studied the effect of various enzyme denaturing agents on the activity of soluble $\beta$ galactosidase ( $\beta$ G), Con A-Celite adsorbed $\beta$ galactosidase $(A \beta G)$ and crosslinked Con $A$-Celite adsorbed $\beta$ galactosidase ( $C \beta \mathrm{G}$ ). The study deal with the immobilization of Aspergillus oryzae $\beta$ galactosidase on concanavalin A layered Celite 545 as bioafinity support.

The covalent link between enzyme and clay at immobilization process can improve reusability, and storage stability of enzymes, An et al. (2015). The presence of organic functional molecules in clay minerals enhances the interactions between enzymes and modifies clay minerals. Clay minerals modified with organic functional molecules as supports can host an increased amount of enzymes.

\section{Conclusion}

In this research, we have isolated and identified bacteria capable in producing cellulase isolated from solid waste of seaweed processing industry. The identity of bacterial isolates were determined based on 16S rRNA sequence, and they are identified as Serratia marcescens, Chryseobacterium indovlogenes, Bacillus pumilus, Bacillus cereus, Strenatrophomonas maltophila, and Pseudomonas aeruginosa. 


\section{Acknowledgment}

This work was supported by Research Centre for Marine and Fisheries Product Processing and Biotechnology, Jakarta Indonesia. We also acknowledge to Dr. Ekowati Chasanah and Dr. Agustinus Robert Uria for support, contribution, comments and revision during the preparation of this manuscript.

\section{References}

Ahmad, F., lqbal, S., Anwar, S., Afzal, M., Islam, E., Mustafa, T., \& Khan, Q.M. (2012). Enhanced remediation of chlorpyrifos from soil using ryegrass (Lollium multiflorum) and chlorpyrifos-degrading bacterium Bacillus pumilus C2A1. Journal of Hazardous Materials, 237-238, 110-115. doi:10.1016/j.jhazmat. 2012.08.006.

Akbulut, N., \& Tuzlako, M. (2013). Improved activity and thermostability of Bacillus pumilus lipase by directed evolutions,? 164, 123-129. doi:10.1016/j.jbiotec. 2012.12.016

An N., Zhou C.H., Zhuang X.Y., Tong D.S., Yu.W.H. (2015). Immobilization of enzymes on clay minerals for biocatalysts and biosensors. Applied Clay Science 114. 283-296. http://dx.doi.org/10.1016/j.clay. 2015.05.029.

Anderson, M. \& Habiger, J. (2012). Characterization and identification of productivity assosiated rhizobacteria in wheat. Appl. Environ. Microbiol. 78: 4434-4446.

Ansari S.A. \& Husain Q. 2012. Lactose hydrolysis from milk/whey in batch and continuous processes by concanavalin A-Celite 545 immobilized Aspergillus oryzae galactosidase. Food and Bioproducts Processing 90: 351-359. doi:10.1016/j.fbp.2011. 07.003.

Araujo, D. M., Yoshida, M. I., Takahashi, J. A., Carvalho, C. F., \& Stapelfeldt, F. (2010). International Biodeterioration \& Biodegradation Biodegradation studies on fatty amines used for reverse $\mathrm{fl}$ otation of iron ore. International Biodeterioration \& Biodegradation, 64(2),151-155. doi:10.1016/j.ibiod. 2010.01.004.

Ariffin, H., Hassan, M., Shah, UK., Abdullah, N., Ghazali, FM., \& Shirai Y. (2008). Production of bacterial endoglucanase from pretreated oil palm empty fruit bunch by Bacillus pumilus EB3. J. Biosci Bioeng 106: 231-236.

Bergquist, P. L., Gibbs, M. D., Morris, D. D., Te'o, V. S. J., Saul, D. J., \& Morgan, H. W. (1999). Molecular diversity of thermophilic cellulolytic and hemicellulolytic bacteria. FEMS Microbiology Ecology. doi:10.1016/ S0168-6496(98)00078-6.

Boran, H., Terzi, E., Altinok, I., Capkin, E., \& Bascinar, N. (2013). Bacterial diseases of cultured Mediterranean horse mackerel (Trachurus mediterraneus) in sea cages. Aquaculture, 396-399, 8-13. doi:10.1016/ j.aquaculture.2013.02.025.

Buresova, V., Hajdusek, O., Franta, Z., Sojka, D., \& Kopacek, P. (2009). IrAM - An a2-macroglobulin from the hard tick Ixodes ricinu $\mathrm{s} /$ : Characterization and function in phagocytosis of a potential pathogen Chryseobacterium indologenes. Dev. \& Comparative Immunology, 33: 489-498. doi:10.1016/j.dci.2008.09.011.

Calderón, G., García, E., Rojas, P., García, E., Rosso, M., \& Losada, A. (2011). Chryseobacterium indologenes infection in a newborn/: a case report. Journal of Medical Case Reports, 5:10. doi:10.1186/1752-19475-10.

Chan, X. Y., Chang, C. Y., Hong, K. W., Tee, K. K., Yin, W. F., \& Chan, K. G. (2013). Insights of biosurfactant producing Serratia marcescens strain W2 . 3 isolated from diseased tilapia fish/ : a draft genome analysis. Gut Pathogens, 5(1),1. doi:10.1186/1757-4749-5-29.

Chang, Y., Lo, H., \& Hsieh, H. (2014). Identification, epidemiological relatedness, and biofilm formation of clinical Chryseobacterium indologenes isolates from central Taiwan. Journal of Microbiology, Immunology and Infection, (666), 1-6. doi:10.1016/ j.jmii.2014.04.004.

Cho, SH., Lee, KS., Shin, DS., Han, JH., Park, KS., Lee, CH., Park, KH., \& Kim, SB. (2010). Four new species of Chryseobacterium from the rizosphere of coastal sand dune plants, Chryseobacterium elyme sp. Nov., Chryseobacterium hagamense sp.nov., Chry seobacterium lathyri sp.nov. and Chryseobacterium rhizosphareae sp.nov. Syst Appl Microbiol 33, 122127.

Cycon, M., Zmijowska, A., Wójcik, M., \& Seget, ZP. (2013). Biodegradation and bioremediation potential of diazinon-degrading Serratia marcescens to remove other organophosphorus pesticides from soils, J. Environ. Manage, 15;117, 7-16. doi:10.1016/j.jenv man. 2012. 12.031.

Del Pozo, MV., Arrojo, LF., Martínez, JG., Montesinos, A., Chernikova, TN., Nechitaylo, TY., Waliszek, A., Tortajada, M., Rojas, A., Huws, SA., Golyshina, OV., Newbold, CJ., Polaina, J., Ferrer, F., \& Golyshin, PN. (2012). Microbial $\beta$-glucosidases from cow rumen metagenome enhance the saccharification of lignocellulose in combination with commercial cellulase cocktail. Biotechnol Biofuels. 5: 73-78.

Edembe, L., Gounel, S., Cadet, M., Durand, F., \& Mano, N. (2012). Electrochemistry Communications A highly efficient $\mathrm{O}_{2}$ cathode cathode based on bilirubin oxidase from Bacillus pumilus operating in serum. Electrochemistry Communications, 23, 80-82. doi:10.1016/j.elecom.2012.07.013

Gao, J., Ye, J., Ma, J., Tang, L., \& Huang, J. (2014). Biosorption and biodegradation of triphenyltin by Stenotrophomonas maltophilia and their influence on cellular metabolism. Journal of Hazardous Materials, 276, 112-119. doi:10.1016/j.jhazmat. 2014.05.023

Garazi, M., Singer, C., Tai, J., \& Ginocchio, C. C. (2012). Bloodstream infections caused by Steno trophomonas maltophilial : a seven-year review. Journal of Hospital Infection, 81(2), 114-118. doi:10.1016/j.jhin.2012.02.008

Gargouri, B., Karray, F., Mhiri, N., Aloui, F., \& Sayadi, S. (2011). Application of a continuously stirred tank bioreactor (CSTR) for bioremediation of hydrocarbon- 
rich industrial waste water effluents. Journal of Hazardous Materials, 189 (1-2), 427-434. doi:10.1016/j.jhazmat.2011.02.057

Ghorbel-Bellaaj, O., Manni, L., \& Jellouli, K. (2012). Optimization of protease and chitinase production by Bacillus cereus SV1 on shrimp shell waste using statistical experimental design. Biochemical and molecular characterization of the chitinase. Annals of Microbiology, 62(3): 1255-1268. doi:10.1007/ s13213-011-0371-x.

Hassanshahian, M., Ahmadinejad, M., Tebyanian, H., \& Kariminik, A. (2013). Isolation and characterization of alkane degrading bacteria from petroleum reservoir waste water in Iran (Kerman and Tehran provenances). Marine Pollution Bulletin, 73: 300-305. http://dx.doi.org/10.1016/j.marpolbul.2013.05.002.

Hasunuma, T., Okazaki, F., Okai, N., Hara, K. Y., Ishii, J., \& Kondo, A. (2013). A review of enzymes and microbes for lignocellulosic biorefinery and the possibility of their application to consolidated bioprocessing technology. Bioresource Technology, 135, 513-522. doi:10.1016/j.biortech.2012.10.047.

Huang, S., Sheng, P., \& Zhang, H. (2012). Isolation and Identification of Cellulolytic Bacteria from the Gut of Holotrichia parallela Larvae (Coleoptera: Scarabaeidae). International Journal of Molecular Sciences. 13(3), 2563-2577. doi:10.3390/ijms130 32563.

Islam, F., Yasmeen, T., Ali, Q., Ali, S., Saleem, M., Hussain, S., \& Rizvi, H. (2014). Ecotoxicology and Environmental Safety Influence of Pseudomonas aeruginosa as PGPR on oxidative stress tolerance in wheat under $\mathrm{Zn}$ stress. Ecotoxicology and Environmental Safety, 104, 285-293. doi:10.1016/ j.ecoenv.2014.03.008.

Johnsen, H. R., \& Krause, K. (2014). Cellulase activity screening using pure carboxymethylcellulose: Application to soluble cellulolytic samples and to plant tissue prints. International Journal of Molecular Sciences, 15(1), 830-838. doi:10.3390/ ijms15010830.

Jung, K. A., Lim, S., Kim, Y., \& Moon, J. (2013). Bioresource Technology Potentials of macroalgae as feedstocks for biorefinery. Bioresource Technology, 135, 182190. doi:10.1016/j.biortech.2012.10.025.

Kadam, A. A., \& Kamatkar, J. D. (2012). Solid-state fermentation/ : tool for bioremediation of adsorbed textile dyestuff on distillery industry waste-yeast biomass using isolated Bacillus cereus strain EBT1. Environ. Sci. Pollut. Res. Int. doi:10.1007/s11356-0120929-6.

Kampfer, P., Arun, A.B., Young, CC., Chen, WM., Sridhar, KR., \& Rekha, PD. (2010). Chryseobacterium arthrospaerae sp.nov., isolated from the faeces of the pill millipede Arthrospaera magna. Int J Syst Evol Microbiol 60, 1765-1769.

Kumar, PA., Srinivas, TNR., Prasad, AR., \& Shivaji, S. (2011). Identification of Fruity Aroma Producing Compounds from Chryseobacterium.sp Isolated from the Western Ghats, India. Journal Current
Microbiology, 63(2): 193-197. Springer-Verlag. doi: 10.1007/s00284-011-9966-5.

Küppers, T., Steffen, V., Hellmuth, H., Connell, T. O., Bongaerts, J., Maurer, K., \& Wiechert, W. (2014). Developing a new production host from a blueprint/ : Bacillus pumilus as an industrial enzyme producer, 1-11. Microb Cell Fact. doi:10.1186/1475-2859-1346.

Luz, E., Hernandez, J., Bashan, Y., \& Maier, R. M. (2010). Bacillus pumilus ES4/: Candidate plant growthpromoting bacterium to enhance establishment of plants in mine tailings. Environ. Exp. Bot. 69, 343352. doi:10.1016/j.envexpbot.2010.04.014.

Lynd, L. R., Weimer, P. J., Zyl, W. H. Van, \& Isak, S. (2002). Microbial Cellulose Utilization/ : Fundamentals and Biotechnology Microbial Cellulose Utilization. Fundamentals and Biotechnology, 66(3). doi:10.1128/MMBR.66.3.506.

McMinn B.R., Cashdollar J.L., Grimm a.C., \& Fout G.S. (2012). Evaluation of the celite secondary concentration procedure and an alternate elution buffer for the recovery of enteric adenoviruses 40 and 41. Journal of Virological Methods, 179 (2): 423-428. doi:10.1016/j.jviromet.2011.11.017.

Montero-Calasanz, M. C., Go, M., Rohde, M., Schumann, P., Schmid, M., Tindall, B. J., \& Klenk, H. (2013). Chryseobacterium hispalense sp.nov., a plantgrowth-promoting bacterium isolated from a rainwater pond in an olive plant nursery, and emended descriptions of Chryseobacterium defluvii, Chryseobacterium indologenes, Chryseobacterium wanjuense and Chryseobacterium gregarium. Inter. Journal of Systematic and Evolutionary Microbiology. 4386-4395. doi:10.1099/ijs.0.052456-0.

P2HP. (2012). Industri Pengolahan Rumput Laut Nasional, Direktur Jendral Pengolahan dan Pemasaran Hasil Pengolahan Kementerian Kelautan dan Perikanan.

Paraneeiswaran, A., Shukla, S. K., Rao, T. S., \& Prashanth, K. (2014). Chemosphere Removal of toxic Co-EDTA complex by a halophilic solar-salt-pan isolate Pseudomonas aeruginosa SPB-1. Chemosphere, 95, 503-510. doi:10.1016/j.chemosphere.2013.09.107

Patel, V., Patel, J., \& Madamwar, D. (2013). Biodegradation of phenanthrene in bioaugmented microcosm by consortium ASP developed from coastal sediment of Alang-Sosiya ship breaking yard. Marine Pollution Bulletin, 74(1), 199-207. doi:10.1016/j.marpolbul.2013.07.001.

Pozo, M. V. Del, Arrojo, LF., Martínez, JG., Montesinos, A., Chernikova, TN., Nechitaylo, TY., Waliszek, A., Tortajada, M., Rojas, A., Huws, SA., Golyshina OV., Newbold, CJ., Polaina, J., Ferrer, M., \& Golyshin, PN. (2012). Microbial $\beta$-glucosidases from cow rumen metagenome enhance the saccharification of lignocellulose in combination with commercial cellulase cocktail. Biotechnology for Biofuels, $5 ; 73$ doi:10.1186/1754-6834-5-73.

Romano, N., Gioffré, A., Sede, S. M., Campos, E., Cataldi, A., \& Talia, P. (2013). Characterization of cellulolytic 
activities of environmental bacterial consortia from an argentinian native forest. Current Microbiology, 67(2), 138-147. doi:10.1007/s00284-013-0345-2.

Salek, K., Zgola-Grze'skowiakb, A., \& Kaczorek, E. (2013). Colloids and Surfaces B/ : Biointerfaces Modification of surface and enzymatic properties of A chromobacter denitrificans and Stenotrophomonas maltophilia in association with diesel oil biodegradation enhanced with alkyl polyglucosides, 111, 36-42. doi:10.1016/ j.colsurfb.2013.05.021.

Sarma, A., Baruah, R., Borah, M., Kumar, A., Prasanna, H., Boruah, D., \& Bora, T.C. (2014). Bioremediation potential of native hydrocarbon degrading bacterial strains in crude oil contaminated soil under microcosm study. International Biodeterioration \& Biodegradation, 94, 79-89. doi:10.1016/j.ibiod. 2014.03.024.

Siddhanta, A.K, Prasad, K., Meena, R., Presad, G., Mehta, G.K., \& Chhatabar, M.U. (2009). Profiling of cellulose content in Indian seaweed species. Bioresource Technology. 100:6669-6673.

Sharma S., Dogra P., Chauhan G.S., \& Kanwar S.S. (2014). Synthesis of alkyl coumarate esters by celitebound lipase of Bacillus licheniformis SCD11501. Journal of Molecular Catalysis B: Enzymatic. 101:8086. http://dx.doi.org/10.1016/j.molcatb. 2013.12.017.

Souza, E. C., Vessoni-penna, T. C., Pinheiro, R., \& Oliveira, D.S. (2014). International Biodeterioration \& Biodegradation Biosurfactant-enhanced hydrocarbon bioremediation/ : An overview. International Biodeterioration \& Biodegradation, 89, 88-94. doi:10.1016/j.ibiod.2014.01.007.

Sriram, M. I., Kalishwaralal, K., Deepak, V., \& Gracerosepat, R. (2015). Colloids and Surfaces B: Biointerfaces Biofilm inhibition and antimicrobial action of lipopeptide biosurfactant produced by heavy metal tolerant strain Bacillus cereus NK1, 1-3. doi:10.1016/j.colsurfb.2011.02.026.

Suraniti, E., Tsujimura, S., Durand, F., \& Mano, N. (2013). Electrochemistry Communications Thermophilic biocathode with bilirubin oxidase from Bacillus pumilus. Electrochemistry Communications, 26, 4144. doi:10.1016/j.elecom.2012.10.004.

Tripathi, M. \& Garg, SK. (2014). Dechlorination of chloroorganics, decolorization, and simultaneous bioremediation of $\mathrm{Cr} 6+$ from real tannery effluent employing indigenous Bacillus cereus isolate. Springer Berlin Heidelberg. Environ Sci Pollut Res 21(7):5227-5241.doi:10.1007/s11Tr356-013-2479-y.

Venil, C. K., Nordin, N., Zakaria, Z. A., Ahmad, W. A., T, C. N., \& T, C. L. M. G. (2014). Chryseobacterium artocarpi sp . nov ., isolated from the rhizosphere soil of Artocarpus integer. Printed in Great Britain,December 2012, 3153-3159. doi:10.1099/ijs.0.063594-0.

Wang, SL., Hsu, WT., Liang, TW., Yen, YH., \& Wang, CL. (2008). Purification and characterization of three novel keratinolytic metalloproteases produced by Chryseobacterium indologenes TKU014 in a shrimp shell powder medium. Bioresource Technology 99(13): 5679-5686. doi:10.1016/j. biortech.2007.10.024.

Wasi, S., Tabrez, S., \& Ahmad M. (2013). Use of Pseudomonas spp. for the bioremediation of environmental pollutants: a review. Environ Monit Assess doi: 10.1007/s10661-013-3163-x.

Watharkar, DA., Rane, NR., Patil, SM., Khandare, RV., \& Jadhav, JP. (2013). Enhanced phytotransformation of Navy Blue RX dye by Petunia grandiflora Juss with augmentation of rhizospheric Bacillus pumilus strain $\mathrm{PgJ}$ and subsequent toxicity analysis. Bioresource Technology, 142: 246-254.

Wijengsihe WAJP, Jeon YJ. 2012. Enzyme-Assistant Extraction (EAE) of bioactive component : a useful approach for $r$ ecovery of industrially important metabolites from seaweeds: A review. Fitoterapia. 83:6-12.

Zamora, L., Fernández-garayzábal, J. F., Palacios, M. A., \& Sánchez-porro, C. (2012). Chryseobacterium oncorhynchi sp. nov ., isolated from rainbow trout (Oncorhynchus mykiss). Systematic and Applied Microbiology, 35(1): 24-29. doi:10.1016/j.syapm. 2011.10.002 